\title{
The Status of Iron Stores in the Women with Beta Thalassemia Minor
}

\section{Beta Talasemi Minörlü Kadınlarda Demir Depolarının Durumu}

\author{
(1) Tahsin KARAASLAN1, id Havva KESKIN22, io Kenan ÇADIRCI3, id Günçağ DİNÇOL ${ }^{4}$
}

1Medeniyet University Faculty of Medicine, Göztepe Training and Research Hospital, Department of Nephrology, İstanbul, Turkey

${ }^{2}$ Medeniyet University Faculty of Medicine, Göztepe Training and Research Hospital, Department of General Internal Medicine, İstanbul,

Turkey

3University of Health Sciences Turkey, Erzurum Regional Training and Research Hospital, Clinic of General Internal Medicine, Erzurum,

Turkey

4̇̇stanbul University İstanbul Faculty of Medicine, Department of Hematology, İstanbul, Turkey

\section{ABSTRACT}

Objective: Patients with beta-thalassemia minor are often exposed to unnecessary iron replacement therapies due to hypochrome microcytic change in erythrocyte morphology. However, in these patients, ineffective erythropoiesis may increase iron absorption in the intestines and excessive iron accumulation in the body. In this study, retrospectively, we aimed to show the iron storage status in our patients with beta-thalassemia minor with both biochemical parameters and bone marrow examinations.

Methods: Fifteen beta-thalassemia minor patients, who underwent bone marrow aspiration and biopsy for any reason in our hospital but had no additional diagnosis except thalassemia, were detected from the hospital records. Their related laboratory values were examined retrospectively. The pathological materials were reevaluated for erythroblast, and sideroblast.

Results: The median age was 43 [interqurtile range (IQR): $27-$ 54] years and the median ferritin values was 24 (IQR: 14.1-84.8) $\mathrm{ng} / \mathrm{mL}$. The ferritin values was $15 \mathrm{ng} / \mathrm{mL}$ in four cases. Sideroblast values were under the normal limit in all but one case. The median sideroblast value was 6\% (IQR: 1.5-15.0\%). Transferrin saturation was less than $20 \%$ in only one case. There was a moderate positive correlation between ferritin and sideroblast $(r=+0.598 ; p=0.032)$ while there was not any positive or negative significant correlation between other parameters.
ÖZ

Amaç: Beta talasemi minörlü hastalar eritrosit morfolojilerindeki hipokrom mikrositer değişiklik nedeniyle sıklıkla demir eksikliği anemisiyle karışarak gereksiz demir replasman tedavilerine maruz kalmaktadırlar. Halbuki bu hastalarda var olan inefektif eritropozisden dolayı bağırsaklarda demir emilimi artabilir ve vücutta aşırı demir birikimi oluşabilir. Bizde kendi hastane verilerimizi retrospektif olarak inceleyerek, bizim hasta grubumuzdaki demir depo durumunu hem biyokimyasal parametreler hem de kemik iliği incelemeleri ile göstermeyi amaçladık.

Yöntemler: Herhangi bir sebeple hastanemizde kemik iliği aspirasyon ve biyopsisi yapılmış ancak talasemi dışında ek bir tanı almamış, 15 beta-talasemi minör hastası sistemden tespit edilip ilgili laboratuvar değerleri retrospektif olarak incelendi. Ayrıca hastalara telefon ile ulaşılarak gerekli ek bilgiler sorgulandı. Arşivden çıkartılan patolojik materyaller durumdan habersiz bir patoloğa gönderildi ve ilgili kemik iliği preparatları eritroblast, sideroblast ve ring sideroblast açısından yeniden değerlendirildi.

Bulgular: Hastaların mediyan yaş: 43 [çeyrekler açılı̆̆ğı (IQR): 27-54] yll, medyan ferritin düzeyi ise $24 \mathrm{ng} / \mathrm{mL}(14,1-84,8)$ idi. Dört olguda ferritin $15 \mathrm{ng} / \mathrm{mL}$ nin altındaydı. Bir olgu dışında tüm olgularda sideroblast değeri normalin altında tespit edildi. Medyan sideroblast değeri \% $6(1,5-15,0)$ idi. Transferrin satürasyonu sadece
Address for Correspondence: Tahsin KARAASLAN, Medeniyet University Faculty of Medicine, Göztepe Training and Research Hospital, Department of Nephrology, İstanbul, Turkey

E-mail: drtkaraaslan@hotmail.com ORCID ID: orcid.org/0000-0002-1529-1790
Received: 15.12 .2019

Accepted: 25.06 .2020

Cite this article as: Karaaslan T, Keskin H, Çadırcı K, Dinçol G. The Status of Iron Stores in the Women with Beta Thalassemia Minor.. Bezmialem Science 2021;9(4):387-393. 
Conclusion: In this study, where iron storage status was examined both biochemically and histopathologically, $66 \%$ of cases with iron deficiency could have been overlooked if the iron status of the patients was evaluated only by the serum iron panel. The examination of bone marrow aspiration with prussian blue is a gold standard method for determining iron storage status.

Keywords: Thalassemia minor, ferritin, sideroblast, iron stores bir olguda \%20'nin altında bulundu. Ferritin ile sideroblast arasında orta derecede pozitif bir korelasyon vardı $(\mathrm{r}=+0,598 ; \mathrm{p}=0,032)$. Diğer parametreler arasında ise pozitif veya negatif herhangi anlamlı bir korelasyon yoktu.

Sonuç: Rutin günlük pratikte demir depolarını ferritin, transferritin satürasyonu ve serum demiri ile değerlendirmekteyiz. Demir depo durumunun hem biyokimyasal hem de histopatolojik olarak incelendiği bu çalışmamızda, sadece serum demir paneline bakarak hastaların demir durumu değerlendirilmiş olunsaydı demir eksikliği olan olguların \%66'sı gözden kaçmış olacaktı. Kemik iliği aspirasyonun prusya mavisi ile incelenmesi demir depo durumunu gösteren altın standart bir yöntemdir.

Anahtar Sözcükler: Talasemi minör, ferritin, sideroblast, demir depoları

\section{Introduction}

The term "thalassemia" defines a group of diseases that are generally characterized by hypochromic microcytic anemia due to a decrease in the synthesis rate, without showing a structural disorder of one or more polypeptide chains of hemoglobin as a result of an inherited defect (1). While hemolysis is prominent in alpha thalassemia, ineffective erythropoiesis is more prominent in beta thalassemia $(2,3)$.

$\beta$-thalassemia is caused by point mutations in the $\beta$-globin gene. It is common in the Mediterranean population and its frequency is up to $10 \%$. $\beta$-thalassemia resulting from an inherited defect of one of the beta genes presents as " $\beta$-thalassemia minor" clinically, and although the defect in erythrocyte morphology is evident in these patients, anemia is mild or absent (3). Clinically, it is usually asymptomatic. These patients are often confused with iron deficiency anemia due to the defect in erythrocyte morphology and are exposed to unnecessary iron replacement therapy $(3,4)$.

Unlike iron deficiency anemia, the presence of prominent erythrocytosis besides deep microcytosis stands out. The Mentzer index, which is the ratio of the mean erythrocyte volume (MCV) to the erythrocyte count, is found to be less than 13 . This ratio is generally greater than 13 in iron deficiency (5). Peripheral smear shows hypochromic microcytosis as well as basophilic spotting, Heinz bodies and target cells. Again, a red cell distribution volume (RDW) of less than 16 is considered in favor of $\beta$-thalassemia minor (6). In addition, $\beta$-thalassemia minor is diagnosed by detecting hemoglobin (HbA2) over 3.5\% in Hb electrophoresis.

While excessive iron accumulation occurs in the body due to frequent transfusions in patients with thalassemia major, iron accumulation may be evident in thalassemia intermedia even though there is no transfusion. This has been attributed to increased intestinal iron absorption due to ineffective erythropoiesis $(7,8)$. It has been shown that hepcidin is suppressed due to increased erythropoiesis in patients with $\beta$-thalassemia minor, resulting in increased intestinal iron absorption $(9,10)$.
In addition to studies reporting that the frequency of iron deficiency is lower in these individuals than in the normal population (11-13), there are also publications suggesting that this frequency does not change (14-17). However, it is a fact that these patients are often misdiagnosed as having iron deficiency anemia due to the similarities in erythrocyte morphology and are frequently exposed to unnecessary iron therapy $(3,4)$. Only female patients were included in our study since iron deficiency was observed more frequently in women and they were exposed to iron treatment more frequently. In some previous studies, there were studies stating that iron absorption increased and less iron deficiency was observed in thalassemia carriers. In fact, if such a situation existed in thalassemia carriers, we would have found less iron deficiency in this study, and even we would find a little higher iron level in individuals without iron loss. Based on this theory, this study was designed. Various studies were done with this theory before, but unlike biochemical iron indicators in our study, bone marrow aspiration and biopsy materials were also used. Thus, we aimed to show whether iron absorption actually increased or not, and to have the chance to compare the biochemical parameters and the results of aspiration and biopsy among themselves.

\section{Methods}

Patients with $\beta$-thalassemia minor who underwent bone marrow aspiration and biopsy in our hospital for any reason in the last 5 years, but did not receive any additional diagnosis other than thalassemia, were detected in the system, and their examinations and related laboratory values [hemoglobin and hematocrit levels, MCV, mean erythrocyte volume) hemoglobin (MCH), erythrocyte count (RBC), MCV/erythrocyte count ratio (Mentzer index), reticulocyte count, morphological features of erythrocytes in hemoglobin electrophoresis and peripheral smear, serum iron values, bone marrow aspiration and biopsy reports] were analyzed retrospectively. Fifteen patients diagnosed as having $\beta$-thalassemia minor were selected for this study. Required additional information (number of pregnancies/births, menstrual 
status, use of aspirin and other nonsteroidal anti-inflammatory drugs, iron intake and bleeding) was asked by phone call. None of the patients had a history of blood transfusion, gastrointestinal bleeding, frequent use of nonsteroidal anti-inflammatory drugs, and chronic diarrhea. Again, none of them had a history of abortion, miscarriage or delivery within one year before the relevant bone marrow biopsy. Verbal information was given to the patients in the phone calls made with the patients and necessary medical information was noted down. The study was approved by the relevant ethics committee (2019/12-120).

All bone marrow biopsies were evaluated by staining with Prussian blue. The relevant laboratory tests and pathology preparations of 2 patients could not be accessed. Relevant pathology materials were removed from the files and sent to an unaware pathologist, and the relevant bone marrow preparations were re-evaluated in terms of erythroblast, sideroblast and ring sideroblast.

\section{Statistical Analysis}

Descriptive statistical methods were used. Spearman correlation analysis was used for correlation analysis because the number of patients was small. All assessments were performed using SPSS software (version 17.0 for Windows; SPSS Inc., Chicago, USA) and $\mathrm{p}<0.05$ was considered significant for all statistical analyses.

\section{Results}

The general demographic characteristics and laboratory values of the patients are shown in Tables 1 and 2. To summarize shortly; the median age of 15 patients was 43 [interqurtile range (IQR): 27-54] years. Bone marrow aspiration and biopsy results of two patients could not be reached. In four patients, ferritin was below $16 \mathrm{ng} / \mathrm{mL}$, the lower limit for iron storage. The median ferritin level was 24 (IQR: 14.1-84.8) ng/mL. Again, except for one patient, the sideroblast value was below normal. The median sideroblast value was 6 (IQR: 1.5-15) (Table 2).

When we compared ferritin used in routine practice with other values, there was a moderately positive correlation between ferritin and sideroblast $(\mathrm{r}=+0.598 ; \mathrm{p}=0.032)$. There was no significant positive or negative correlation between ferritin and iron $(\mathrm{r}=-0.04 ; \mathrm{p}=0.884)$, iron and sideroblast $(\mathrm{r}=-0.21 ; \mathrm{p}=0.480)$, total iron binding capacity (TIBC) and ferritin $(\mathrm{r}=+0.281$; $\mathrm{p}=0.310)$, TIBC and sideroblast $(\mathrm{r}=-0.197 ; \mathrm{p}=0.518)$, TIBC and iron $(r=-0.214 ; \mathrm{p}=0.444)$, ferritin and transferrin saturation $(\mathrm{r}=-$ $0.05 ; \mathrm{p}=0.869)$, and sideroblast and transferrin saturation $(\mathrm{r}=-$ $0.127 ; \mathrm{p}=0.680)$.

Table 1. Demographic characteristics of the patients

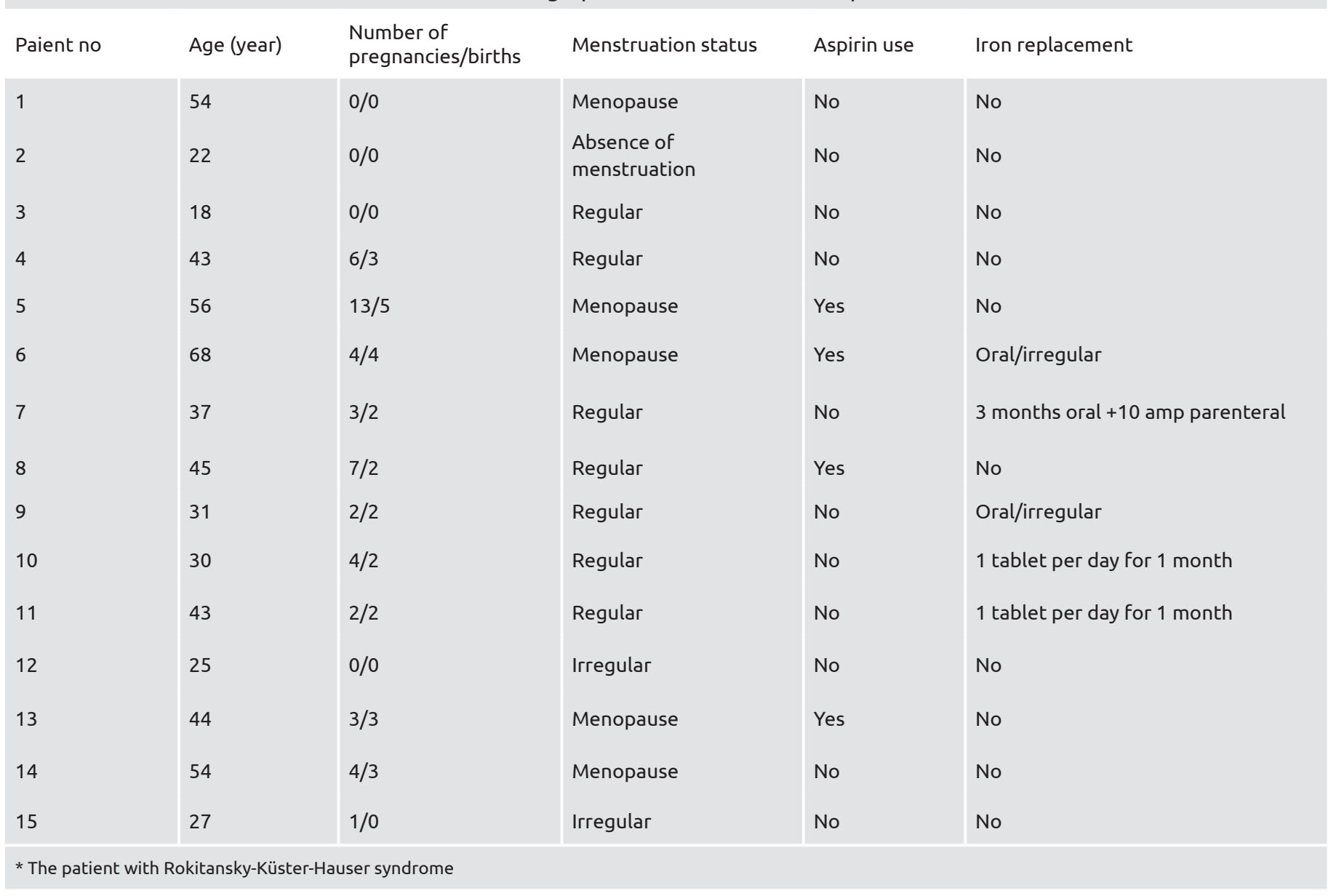


$\frac{\Delta}{0}$
$\frac{0}{0}$
$\frac{0}{4}$

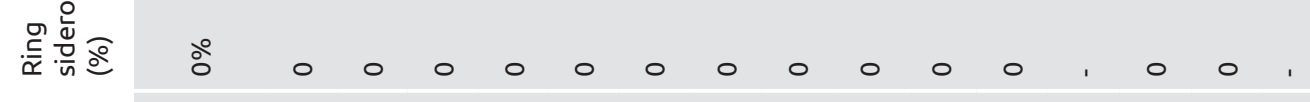
崩

耑

空点

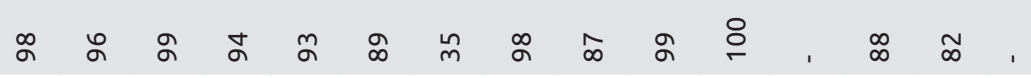

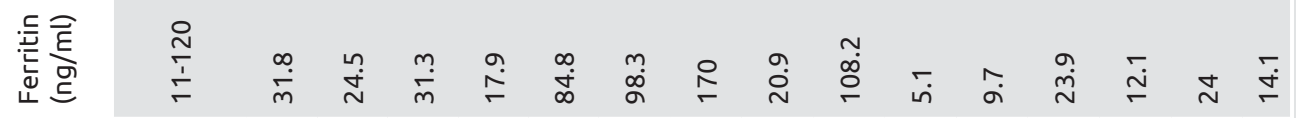

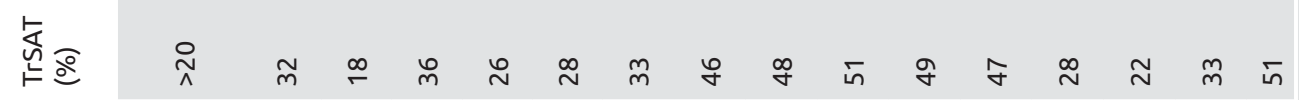

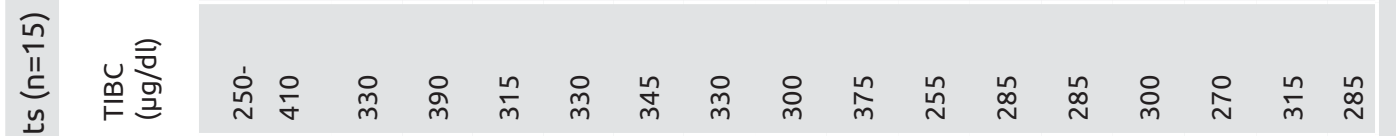
㫕

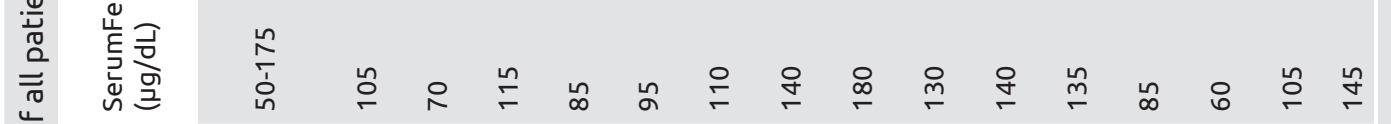
产

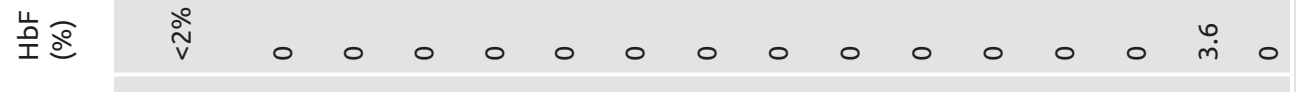

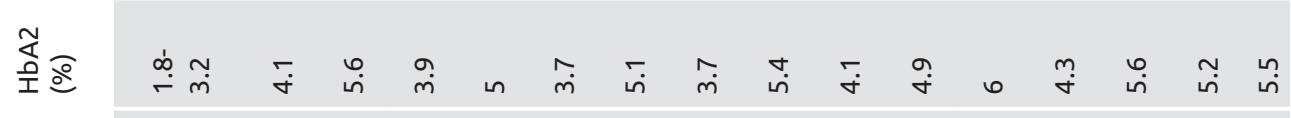

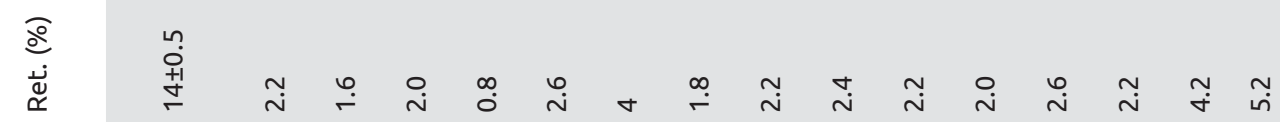
炛

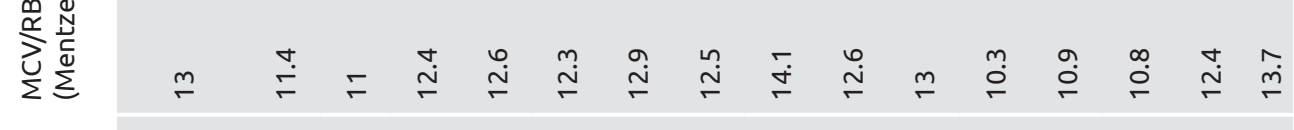

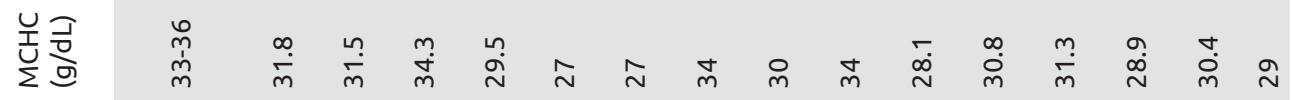

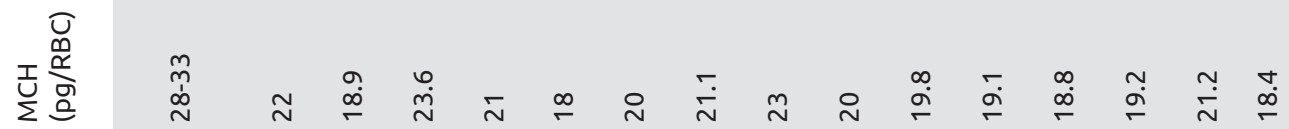

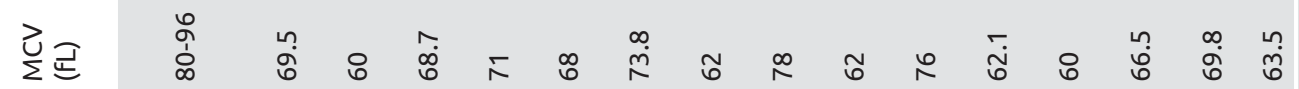

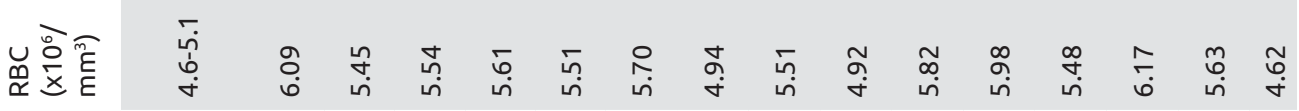

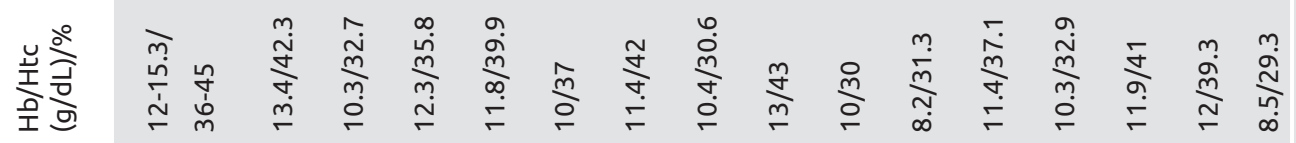

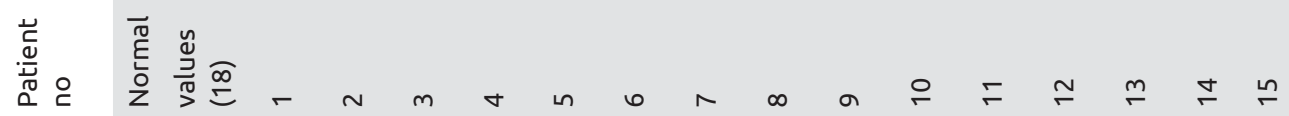




\section{Discussion}

The status of iron stores in people with $\beta$-thalassemia minor has been a matter of interest for years, and many studies have been conducted on this subject. The first study on iron storage status was conducted in 1978 by measuring ferritin in women with $\beta$-thalassemia minor. Various erythrocyte indices are used for screening in the differential diagnosis of $\beta$-thalassemia minor and iron deficiency anemia. England and Fraser's discriminant function, MCV/RBC ratio (Mentzer index), Shine \& Lal index, Green \& King index, RDW index, Ricerca index, Srivastava index, Bessman index, and Ehsani formula are the main indexes used in differential diagnosis (19-21). In patients in whom $\beta$-thalassemia minor is considered as a result of these tests, the diagnosis can be confirmed by $\mathrm{HbA} 2$ and/or DNA analyzes measured using paper chromatography. Bone marrow biopsy has no place in the diagnosis. Therefore, bone marrow examination of these patients is not a method used in routine practice. We aimed to retrospectively evaluate and document the blood values together with these bone marrow aspiration and biopsy results of our patients who were followed up with the diagnosis of $\beta$-thalassemia minor in our clinic, who underwent bone marrow aspiration and biopsy for any reason, but in whom no additional disease was detected as a result of the biopsy.

The frequent confusion between $\beta$-thalassemia minor and iron deficiency anemia, frequent iron replacement without diagnosis, and the knowledge that intestinal iron absorption will increase due to the suppression of hepcidin hormone caused by ineffective erythropoiesis in these patients have brought to mind the hypothesis that iron excess may be present in this group of individuals $(3,4,9,10)$. Starting from this point, we wanted to show the iron storage status both biochemically and histopathologically in this study. Thus, we thought that we would learn more about iron deficiency especially in the prelatent period.

Looking at the patient data, as expected, all our evaluated patients had low MCV, Mentzer index $<13$, and HbA2 $\geq 3.7 \%$. Again, an erythrocytosis that was not compatible with the $\mathrm{Hb}$ value was noted in all of our patients. Mean erythrocyte count of the patients was $5.5 \times 10^{6}$. This erythrocytosis supported the diagnosis of $\beta$-thalassemia minor (22). MCV values were also found to be $\leq 70 \mathrm{fL}$ in our patients. In only four patients, the MCV was between 73-78 fL and was lower than normal. Mean MCV values were $67.4 \mathrm{fL}$. Considering this decrease in MCV values and erythrocytosis, the suspicion of $\beta$-thalassemia minor was strengthened. This was in agreement with the results previously written by Jhon N. Lukens in Wintrobe's Clinical Hematology (3).

Ferritin levels were below the normal value (less than $16 \mathrm{ng} /$ $\mathrm{mL}$ ) (23) in 4 of our patients. In 2 of these 4 patients, serum iron and TIBC were normal, and tranferrin saturation was in the upper limit of normal, due to the iron treatment they received. So the iron stores weren't full yet. In the bone marrow aspirations of these patients, the percentages of sideroblasts were found to be $1 \%, 0 \%$ and $12 \%$. More than half of the erythroblasts in a normal person are made up of sideroblasts, each of which contains fewer than five iron granules. The rate of sideroblasts falls below $30 \%$ in iron deficiency (24). In this study, if the bone marrow was not evaluated and only the transferrin saturation and ferritin were evaluated, we would have said that there was iron deficiency in only 4 patients; however, with the evaluation of bone marrow, we found that this situation was different, except for these 4 patients, all of the patients who underwent biopsy had iron deficiency, except for one patient. In patient 7 , transferrin saturation was $46 \%$ and ferritin level was significantly high $(170 \mathrm{ng} / \mathrm{mL})$. This patient had received long-term oral and parenteral iron therapy before admitting to us. Sideroblasts were detected in $60 \%$ of this patient's bone marrow aspiration. These values were above normal. When the patient was evaluated together with his/her anamnesis, it was determined that there was iron accumulation in his/her body since this patient was given iron replacement therapy considering only the erythrocyte morphology, without diagnosis of thalassemia. This patient supported the hypothesis that if thalassemia awareness did not develop sufficiently, iron overload might occur in these patients due to unnecessary iron replacement. These patients were similar to the 4 patients shown by Hussein et al. (17) in their 1976 study who received unnecessary iron replacement therapy and subsequently developed high ferritin levels.

Although serum iron, TIBC and ferritin values were normal in our other patients, sideroblast rate was found below $12 \%$ in 8 patients and around $20 \%$ in 2 patients in the bone marrow aspirate. That is, if we were to interpret the iron storage status in these patients only by looking at the biochemical values, we would interpret the iron storage status as normal, however, it was observed that the iron stores were insufficient in this group with the bone marrow examination. In previous studies, controlled with serum ferritin and erythrocyte ferritin, it was stated that the iron balance of patients with $\beta$-thalassemia minor was better than the control group, and the frequency of iron deficiency was lower in patients with $\beta$-thalassemia minor. Researchers attributed this to increased iron absorption due to the ineffective erythropoiesis present in patients with $\beta$-thalassemia minor (25-27). Considering the studies conducted by researchers who stated that iron absorption was increased in thalassemia, we should have found the ferritin values of our patients to be normal or even above normal values. However, in our patients, ferritin values were generally in the lower limit of normal, and when we evaluated bone marrow aspiration smears, we found that all patients were in the iron deficiency period, except for one patient. Based on these findings, we can say that iron absorption is not increased in patients with $\beta$-thalassemia minor, which is consistent with the work of Hussein et al. (15-17). This result shows that the theory that an increase in ineffective erythropoiesis will cause a decrease in hepcidin molecule and as a result increase iron absorption from the intestine is not true for $\beta$-thalassemia minor.

When we compared ferritin used in routine practice with other values, there was a moderately positive correlation between ferritin and sideroblast $(\mathrm{r}=+0.598 ; \mathrm{p}=0.032)$. There was no significant 
positive or negative correlation between ferritin and iron $(\mathrm{r}=-$ $0.04 ; \mathrm{p}=0.884)$, iron and sideroblast $(\mathrm{r}=-0.21 ; \mathrm{p}=0.480)$, total iron binding capacity (TIBC) and ferritin $(r=+0.281 ; \mathrm{p}=0.310)$, TIBC and sideroblast $(r=-0.197 ; \mathrm{p}=0.518)$, TIBC and iron $(\mathrm{r}=-$ $0.214 ; \mathrm{p}=0.444)$, ferritin and transferrin saturation $(\mathrm{r}=-0.05$; $\mathrm{p}=0.869)$, and sideroblast and transferrin saturation $(\mathrm{r}=0.127$; $\mathrm{p}=0.680$ ). This showed us once again that the second laboratory value to be evaluated together with ferritin when evaluating iron deficiency was sideroblast. In addition, if we had evaluated only TrSAT and ferritin, we could have missed the diagnosis of iron deficiency in $66 \%$ of the patients. In this case, it can be said that the threshold value of ferritin used in the diagnosis should be kept at higher levels in order not to miss these patients, and larger prospective, case-control studies are needed to make a definite conclusion.

Iron is found in the bone marrow in the form of hemosiderin in the cytoplasm of macrophages. Iron stores can be easily evaluated under the microscope at 20x and 40x magnifications. Prussian stain is used in the iron staining process and the cells having blue granules are considered as positive cells. The presence of more than two positive cells in each $(\mathrm{x} 40)$ magnification area indicates that the iron stores are increased, and the average of less than one positive cell in each area indicates that the iron stores are decreased. When we examined the bone marrow biopsies based on these criteria, all patients had zero iron in the bone marrow. Iron molecule is filtered during the decalcification stage in the iron staining process of the bone marrow biopsy. Therefore, evaluation of bone marrow iron stores by biopsy may give false negative results. In addition, biopsy is evaluated relatively. Although there is a correlation between biopsy and aspiration in showing iron stores, we could not detect this correlation. In our cases, we found that aspiration smear was a more sensitive method than bone marrow biopsy in assessing iron stores, consistent with the literature (28).

Although the number of patients whose bone marrow biopsy was scanned was high, the number of our patients remained low because bone marrow examination did not have a routine place in the diagnosis/follow-up of thalassemia and those with systemic disease affecting the bone marrow and/or additional blood disease were excluded from the study. The small number of patients (15 patients in total) and the retrospective design were the main limitations of our study. In this analysis, we were not only limited to the measurement of serum iron level, TIBC, and ferritin levels, but also had the opportunity to examine in detail the existing bone marrow aspirations and biopsies of these patients. Thus, in addition to investigating the status of iron stores in women with $\beta$-thalassemia minor, we had the chance to compare the diagnostic accuracy of ferritin, bone marrow aspiration smears and bone marrow biopsies.

\section{Conclusion}

In conclusion, we did not find any findings showing increased iron absorption in our patients. Examination of bone marrow aspiration in the evaluation of iron stores gives much better results than biochemical parameters, but the invasiveness of the procedure limits its use in the clinic.

\section{Ethics}

Ethics Committee Approval: The study was approved by the relevant ethics committee (2019/12-120).

\section{Informed Consent:}

Peer-review: Externally peer reviewed.

\section{Authorship Contributions}

Concept: T.K., H.K., K.Ç., Design: T.K., H.K., K.Ç., Data Collection or Processing: T.K., Analysis or Interpretation: T.K., Literature Search: T.K., Writing: T.K., H.K.

Conflict of Interest: No conflict of interest was declared by the authors.

Financial Disclosure: The authors declared that this study received no financial support.

\section{References}

1. Dinçol G. Beta ve Delta-Beta talasemi tiplerinin ayrılmasında hemoglobin analiz sonuçlarının değeri, in İstanbul Tıp Fakültesi İç Hastalıkları, Hematoloji Kliniği. İstanbul Üniversitesi, 1977.

2. Benz EJ. Clinical manifestations and diagnosis of the thalassemias. Aug 19 2019. Available from: www.uptodate.com/MusePath/contents/ clinical-manifestations-and-diagnosis-of-the-thalassemias?search.

3. Borgna-Pignatti C, Galanello Thalassemias R. Related Disorders:Quantitative Disordersof Hemoglobin Synthesis, in Wintrobe's Clinical Hematology, J.P. Greer, J. Foerster, and J.N. Lukens, Editors. LippincottWilliams\&WilkinsPublishers 2004.p.42:1078-118.

4. Bessman JD, Feinstein DI. Quantitative anisocytosis as a discriminant between iron deficiency and thalassemia minor. Blood 1979;53:28893.

5. Ansari S, Rashid N, Hanifa A, Siddiqui S, Kaleem B, Naz A, et al. Laboratory diagnosis for thalassemia intermedia: Are we there yet? J Clin Lab Anal 2019;33:e22647.

6. Massey AC. Microcytic anemia. Differential diagnosis and management of iron deficiency anemia. Med Clin North Am 1992;76:549-66.

7. Musallam KM, Cappellini MD, Wood JC, Motta I, Graziadei G, Tamim H, et al. Elevated liver iron concentration is a marker of increased morbidity inpatients with $\beta$ thalassemia intermedia. Haematologica 2011;96:1605-12.

8. Musallam KM, Cappellini MD, Daar S, Karimi M, El-Beshlawy A, Graziadei G, et al. Serum ferritin level and morbidity risk in transfusion-independent patients with $\beta$-thalassemia intermedia: the ORIENT study. Haematologica 2014;99:218-21.

9. Jones E, Pasricha SR, Allen A, Evans P, Fisher CA, Wray K, et al. Hepcidin is suppressed by erythropoiesis in hemoglobin E betathalassemia and beta- thalassemia trait. Blood 2015;125:873-80. 
10. Huang Y, Lei Y, Liu R, Liu J, Yang G, Xiang Z, et al. Imbalance of erythropoiesis and iron metabolism in patients with thalassemia. Int J Med Sci 2019;16:302-10.

11. Aghai E, Shabbad E, Quitt M, Froom P. Discrimination between Iron Deficiency and Heterozygous beta-thalassemia in children. AJCP 1986;85:710-2.

12. Crosby WH, Conrad ME. Iron Balance In Thalassemia Minor. A Preliminary Report. Ann N Y Acad Sci 1964;119:616-23.

13. Halliday JW, Powell LW. Iron overload. Semin Hematol 1982;19:4253.

14. Bannerman RM, Callender ST, Hardisty RM, Smith RS. IRON ABSORPTION IN THALASSAEMIA. Brit J Haematol 1964;10:490-5.

15. Economidou J, Augustaki O, Georgiopoulou V, Vrettou H, Parcha S, Loucopoulos D. Assessment of Iron Stores in Subjects Heterozygous for $\beta$-thalassaemia Based on Serum Ferritin Levels. Acta Haematol 1980;64:205-8.

16. Hegde UM, Khunda S, Marsh GW, Hart GH, White JM. Thalassaemia, iron, and pregnancy.Br Med J 1975;3:509.

17. Hussein S, Hoffbrand AV, Laulicht M, Attock B, Letsky E. Serum ferritin levels in beta-thalassaemia trait. Br Med J 1976;2:920.

18. Leung, L.L. Approach to the adult with anemia. 2019; Available from: https://www.uptodate.com/contents/approach-to-the-adultwith-anemia.

19. Sonati Mde F, Grotto HZ, Kimura EM, Costa FF. Diferenciação entre talassemia beta-heterozigótica e anemia ferropriva [Differentiation between heterozygotic beta-thalassemia and iron deficiency anemia]. Rev Assoc Med Bras (1992) 1993;39:221-3.
20. Mentzer WC Jr. Differentiation of iron deficiency from thalassaemia trait. Lancet 1973;1:882.

21. Maskoen,A.M.,etal., Shine\&Lalindex asapredictorforearlydetectionof beta-thalassemiacarriers inalimitedresourceareainBandung,Indonesia. BMCMedGenet

22. Aslan D. Automated blood counts and identification of thalassemia carriers. J Postgrad Med 2008;54:242-3.

23. Michael A. Causes and diagnosis of Iron deficiency and Iron deficiencyanemiainadults.2019; Available from: https://www. uptodate.com/contents/causes-and-diagnosis-of-iron-deficiencyand-iron-deficiency-anemia-in-adults.

24. Andrews NC. Iron Deficiency and Related Disorders, in Wintrobes Clinical Hematology. 2003. p. 794-812.

25. Cermák J, Brabec V. Význam vysetrení hladiny feritinu v cervených krvinkách [The importance of determination of ferritin levels in erythrocytes]. Cas Lek Cesk 1990;129:1357-60.

26. Crosby W, Conrad M. Iron balance in thalassemia minor. Problems of Cooley's Anemia: Academy, Ann NY Acad Sci, 1964.

27. Lyberatos C, Chalevelakis G, Platis A, Stathakis N, Panani A, Gardikas C. Erythrocyte content of free protoporphyrin in thalassaemic syndromes. Acta Haematol 1972;47:164-7.

28. Bucley PJ. Examination and interpretation of bone marrow biopsies and aspirate smears. In: Hofman R, Jr. EJB, Shattil SJ, eds. Hematology Basic Principles and Practice, 1993; 2214-2222. 